\title{
HYDRODYNAMIC PROPERTIES OF HIGH TEMPERATURE NATURAL CIRCULATING HELIUM COOLING LOOP
}

\author{
DZIANIK František ${ }^{1}$, GUŽELA Štefan ${ }^{1}$ \\ ${ }^{I}$ Slovak University of Technology in Bratislava, Faculty of Mechanical Engineering, Institute of Process \\ Engineering, Nám. slobody 17, 81231 Bratislava, Slovakia, \\ e-mail: frantisek.dzianik@stuba.sk, stefan.guzela@ stuba.sk
}

\begin{abstract}
The paper deals with the hydrodynamic properties, i.e. the consumption of mechanical energy expressed by pressure drops within a helium loop intended for the testing of decay heat removal (DHR) from the model of a gas-cooled fast reactor (GFR). The system is characterised by the natural circulation of helium, as a coolant, and assume steady operating conditions of circulation. The helium loop consists of four main components: model of gas-cooled fast reactor, model of the heat exchanger for decay heat removal, hot piping branch and cold piping branch. Using the process hydrodynamic calculations, the pressure drops of circulating helium within the main components of the helium loop were determined. The calculations have been done for several defined operating conditions which correspond to the different helium flow rates within the system.
\end{abstract}

KEYWORDS: helium cooling loop, natural circulation, pressure drops, decay heat removal (DHR)

\section{Introduction}

Several new types of nuclear power reactors are currently the subject of research in an attempt to achieve improved safety, reliability and efficiency of nuclear power plants. One promising solution of nuclear reactors are gas-cooled fast reactors (GFR) which rank among the so-called Generation IV reactors. Helium is a suitable heat transfer medium for the primary circuit system and the decay heat removal system in such gas-cooled fast reactors. For this reason, the research of helium cooling loop systems is very topical. The research activities in the given area from several aspects are documented in the various publications, as for example [1, 2, 3, 4, 5].

The cooling loop systems can be divided, in a processes point of view, into systems with forced or natural circulation of the cooling fluid. Helium cooling loop, for which the hydrodynamic process properties are presented in this paper, can be defined as a model of passive safety serving to remove heat from the fast reactor working space (the active zone of gas-cooled fast reactor) in the event of an emergency. From a processes point of view, the operation of such a helium cooling loop is based on a combination of thermal and hydrodynamic processes that are interdependent. The geometric configuration of the system has a very significant influence on the qualitative and quantitative aspects of the thermohydrodynamic processes.

\section{Operational and design features of helium cooling loop}

The high temperature helium cooling loop (Fig. 1) is a device intended for the experimental testing of decay heat removal (DHR) from the model of gas-cooled fast reactor (GFR). The cooling loop consists of four main components: model of the gas-cooled fast reactor (1), model of the heat exchanger for decay heat removal (2), hot piping branch (3) and cold piping branch (4). The GFR model is used to simulate a source of decay heat generated 
by electric heating through heating elements (rods). The model of DHR heat exchanger is used for the heat removal which is generated in the reactor model. This is a standard recuperative shell and tube heat exchanger with U-tubes. The GFR model and the heat exchanger model are interconnected through the hot piping branch and the cold piping branch. The primary heat transfer fluid is helium. The secondary cooling fluid in the DHR heat exchanger model is water. The cooling water flows in the tube side and helium in the shell side of the heat exchanger model.

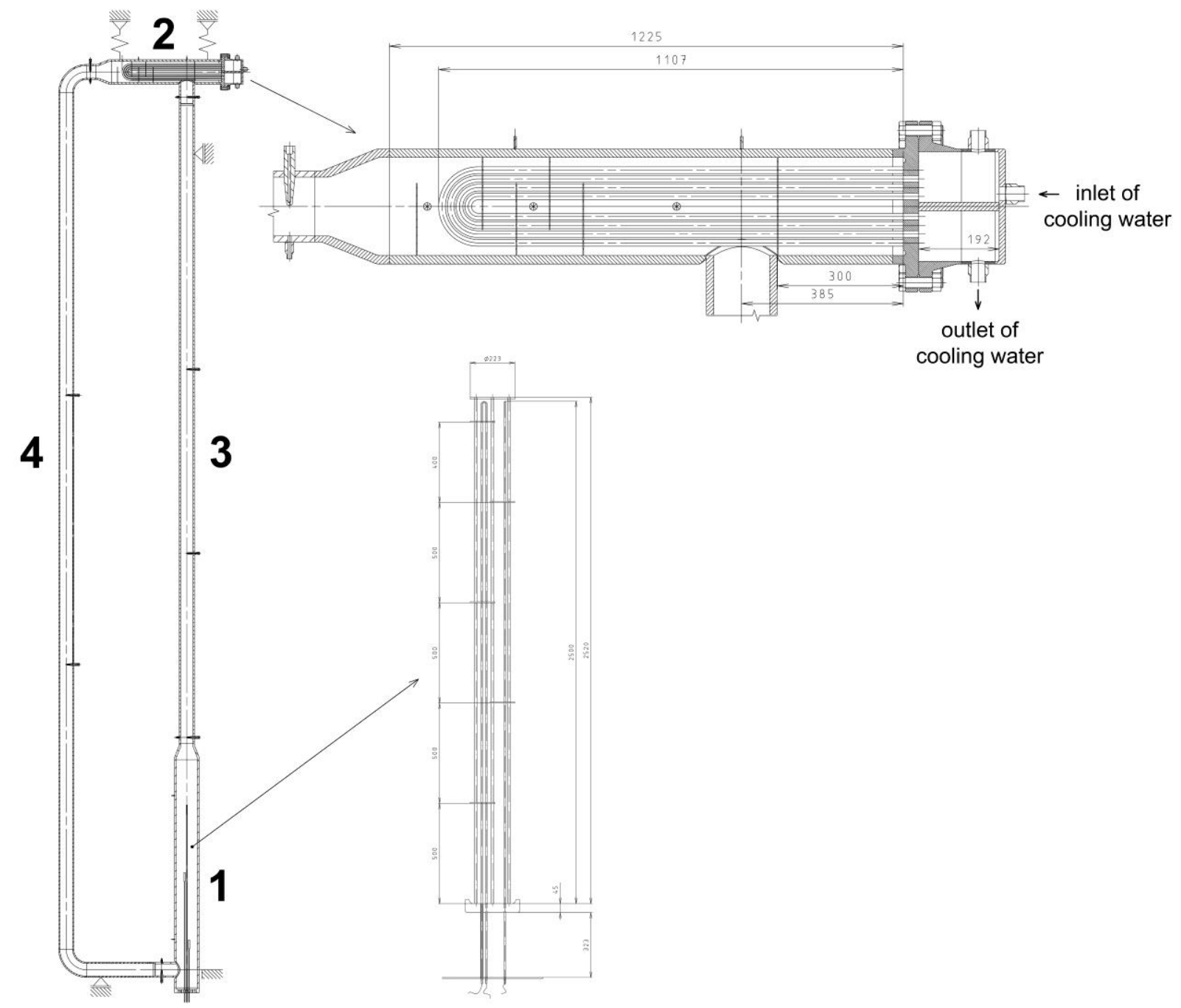

Fig. 1 High temperature helium cooling loop [4]

(1 - GFR model, 2 - DHR heat exchanger model, 3 - hot piping branch, 4 - cold piping branch).

The helium cooling loop must ensure a passive heat removal from the reactor model, i.e., it must be able to achieve a sufficiently intensive natural circulation (circulation caused by the effect of gravity) of helium in the cooling system due to a helium density difference in the cold and hot piping branch. Within such helium circulation the appropriate thermohydrodynamic conditions have to be achieved in the reactor model in order to ensure the desired heat flow rate removal from the surface of heating elements (rods) to the heat transfer fluid (helium). In order to ensure the steady transfer of this heat flow rate from helium to the cooling water, the appropriate thermo-hydrodynamic conditions have to be achieved simultaneously also in the heat exchanger model. In the steady operating condition of the helium cooling loop, it may be assumed that the flow of the helium in the hot and cold piping branch is isothermal. The heated helium has to flow upward in the hot piping branch from the 
reactor model to the heat exchanger model, and the cooled helium has to flow downwardly in the cold piping branch from the heat exchanger model to the reactor model.

The helium section of cylindrical shell $(\varnothing 273 \times 20 \mathrm{~mm})$ in the DHR heat exchanger model is made of low alloy heat resistant steel. The cooling water section of the shell as well as the tube bundle and the tube sheet are made of stainless steel. The tube bundle consists of twenty U-tubes $\varnothing 16 \times 1.5 \mathrm{~mm}$ with a length of $2.2 \mathrm{~m}$, which are fixed in the tube sheet. The heat exchanger shell side internals consists of some segmented baffles (baffle spacing $80 \mathrm{~mm}$ ) to direct the flow of helium and to support the tubes. The GFR model is a cylindrical pressure vessel $(\varnothing 273 \times 20 \mathrm{~mm})$ with a flat bottom and is made of low alloy heat resistant steel. The reactor model internals consists of longitudinal heating rods $(8.5 \mathrm{~mm}$ in diameter and $2.5 \mathrm{~m}$ long) and the segmental baffles (baffle spacing $500 \mathrm{~mm}$ ) to direct the flow of helium and to support the heating rods. The hot piping branch and the cold piping branch are made of low alloy heat resistant steel. They consist basically of straight vertical pipes $\varnothing 168.3 \times 14.2 \mathrm{~mm}$.

\section{Methodology and conditions of the hydrodynamic calculations}

Thermo-hydrodynamic process calculations of the helium cooling loop components have been performed for the defined operating conditions listed in Tab. 1. The necessary mass flow rates of helium and cooling water arise from the thermal calculations of the model of gascooled fast reactor (GFR) and the model of the heat exchanger for decay heat removal (DHR). Thermal calculations are not included in this paper. Based on the mass flow rates of helium $m_{H e E}$ and cooling water $m_{W E}$, it is possible, through hydrodynamic calculations, to determine the values of the pressure drops in the model of the DHR heat exchanger for helium $\Delta p_{d H e E}$ and for cooling water $\Delta p_{d W E}$. Similarly, based on the mass flow rates of helium $m_{H e R}$, it is possible to determine the values of the pressure drops in the GFR model for helium $\Delta p_{d H e R}$. The methodology of process calculations of heat exchangers may be found in various specialized publications such as the VDI-Wärmeatlas [6].

Tab. 1 Defined operating conditions for thermo-hydrodynamic process calculations of the helium cooling loop components.

\begin{tabular}{|l|c|c|}
\hline \multicolumn{1}{|c|}{ Parameter } & Symbol & Value \\
\hline Operating pressure of the helium & $p_{H e}(\mathrm{MPa})$ & 7 \\
Temperature of helium at the inlet of heat exchanger model & $T_{\mathrm{HeEI}}\left({ }^{\circ} \mathrm{C}\right)$ & 520 \\
Temperature of cooling water at the inlet of heat exchanger model & $T_{W E I}\left({ }^{\circ} \mathrm{C}\right)$ & 15 \\
Temperature of cooling water at the outlet of heat exchanger model & $T_{W E O}\left({ }^{\circ} \mathrm{C}\right)$ & 45 \\
Temperature of helium at the inlet of reactor model & $T_{H e R I}\left({ }^{\circ} \mathrm{C}\right)$ & 150 \\
Temperature of helium in the hot piping branch & $T_{\mathrm{HeH}}\left({ }^{\circ} \mathrm{C}\right)$ & 520 \\
Temperature of helium in the cold piping branch & $T_{\mathrm{HeC}}\left({ }^{\circ} \mathrm{C}\right)$ & 200 \\
\hline
\end{tabular}

The hydrodynamic calculation of hot and cold piping branch of the system includes the determination of pressure drop due to friction and local pressure drop in each piping branch [7]. The total pressure drops $\Delta p_{d}$ in each piping branch are the sum of the frictional $\Delta p_{d f}$ and local $\Delta p_{d l}$ pressure drops in these piping branches $\left(\Delta p_{d}=\Delta p_{d f}+\Delta p_{d l}\right)$. The frictional pressure drop $\Delta p_{d f}$ is possible to calculate for one-dimensional flow of fluid in the pipe theoretically, using the Darcy-Weissbach equation: 


$$
\Delta p_{d f}=\lambda \frac{L}{D} \rho \frac{v^{2}}{2}
$$

where $\lambda$ is the friction factor, $L$ is the length of the pipe section, $D$ is the internal pipe diameter, $v$ is the mean velocity of fluid in the pipe and $\rho$ is the density of the flowing fluid. Generally, the value of the friction factor $\lambda$ depends on the value of the Reynolds number $\operatorname{Re}$ and on the relative roughness $k^{*}$ of the inner surface of the pipe. Churchill's equation can be used to evaluate the friction factor:

$$
\lambda=8\left[\left(\frac{8}{\operatorname{Re}}\right)^{12}+\frac{1}{(a+b)^{1.5}}\right]^{\frac{1}{12}}
$$

where

$$
\begin{aligned}
& a=\left[2.457 \ln \frac{1}{\left(\frac{7}{\operatorname{Re}}\right)^{0.9}+0.27 k^{*}}\right]^{16}, \\
& b=\left(\frac{37530}{\operatorname{Re}}\right)^{16} \text {. }
\end{aligned}
$$

The described method of the theoretical calculation of frictional pressure drops does not reflect the impact of so-called stabilising pipe sections on which the flow velocity profiles are formed. This fact affects the accuracy of frictional pressure drop calculations mainly in short pipe sections. The following equation has been used to calculate the local pressure drops $\Delta p_{d l}$ in the piping branches:

$$
\Delta p_{d l}=\zeta \rho \frac{v^{2}}{2}
$$

In equation (5), the values of local drag coefficient $\zeta$ depend mainly on the geometric configuration of the objects (pipe fittings) in the piping branches which cause the local hydraulic resistances to fluid flow.

\section{$4 \quad$ Results}

The results of the calculations are presented in the form of graphs. In Fig. 2, the dependence of the pressure drop in the shell side of the DHR heat exchanger for helium $\Delta p_{d H e E}$ on the helium mass flow $m_{H e E}$ is plotted, and Fig. 3 shows the dependence of the pressure drop in the tube side of the DHR heat exchanger for cooling water $\Delta p_{d W E}$ on the mass flow of the cooling water $m_{W E}$ under the given conditions. The graphs also contain the values of the corresponding transferred heat flow rates $Q$ and the temperature values of helium $T_{\mathrm{HeEO}}$ at the outlet of the DHR heat exchanger model. 


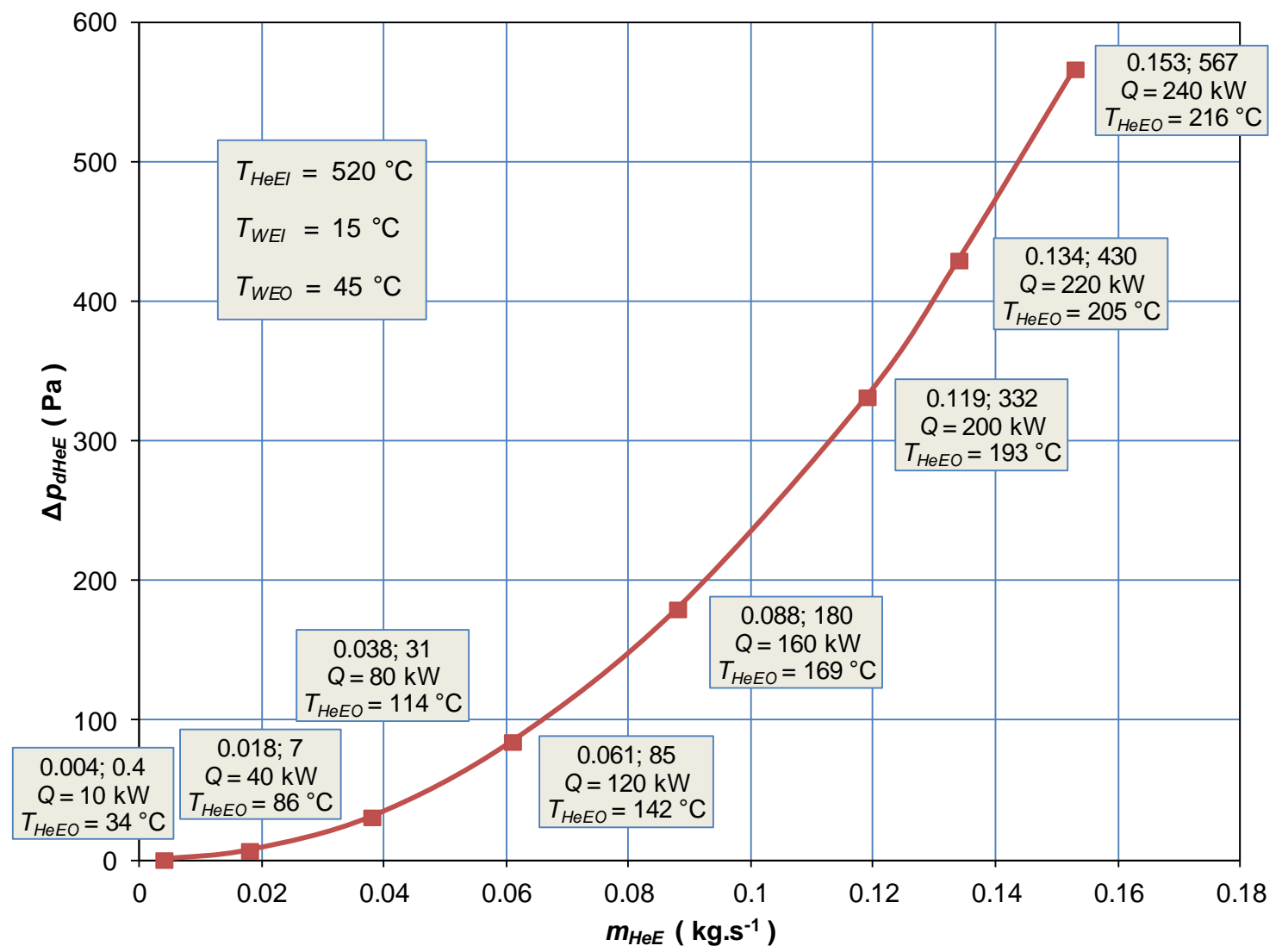

Fig. 2 The dependence of pressure drop on the helium mass flow within the heat exchanger.

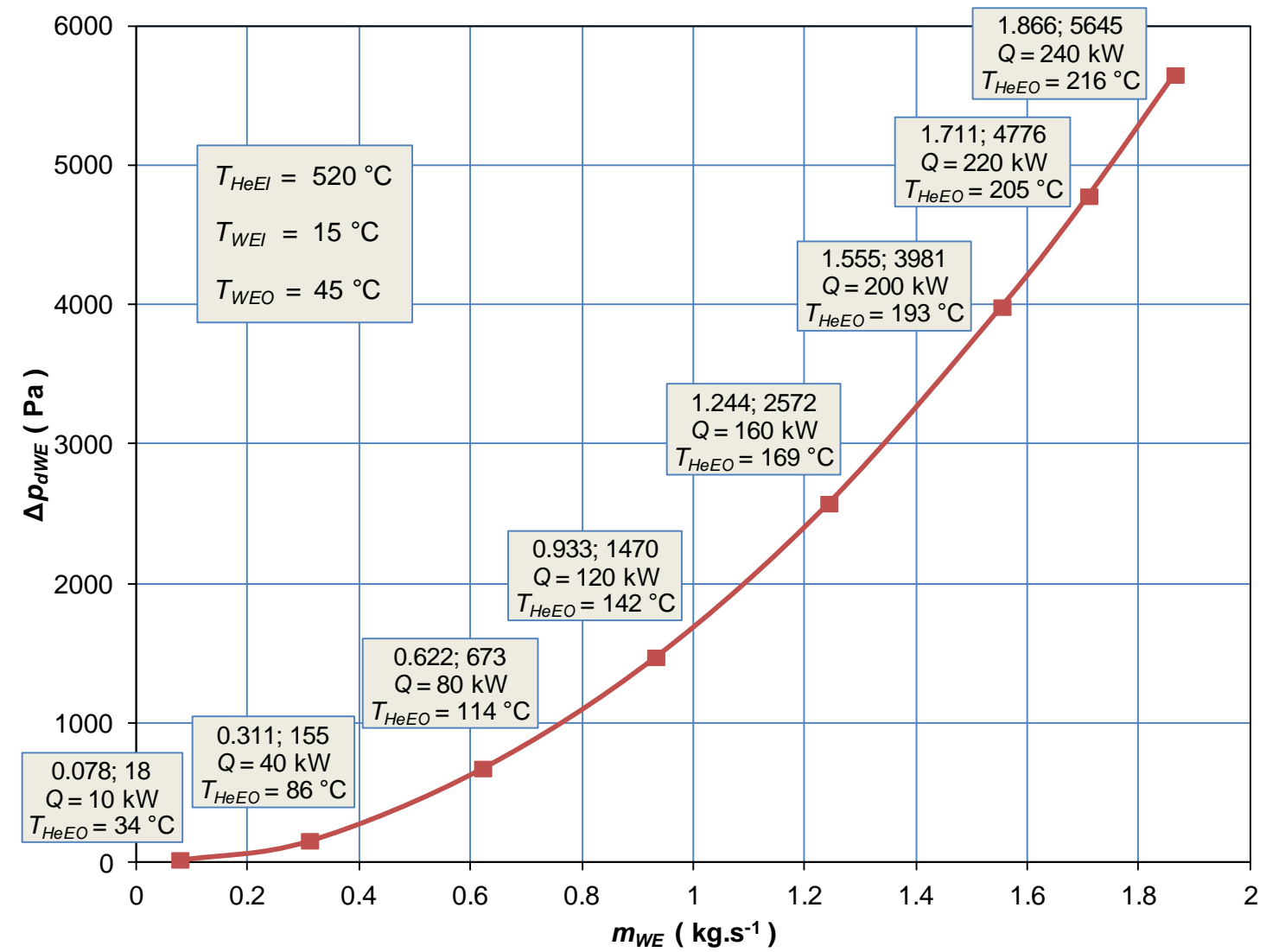

Fig. 3 The dependence of pressure drop on the cooling water mass flow within the heat exchanger. 
The Fig. 4 shows the dependence of the pressure drop in the model of gas-cooled fast reactor (GFR) for helium $\Delta p_{d H e R}$ on the helium mass flow $m_{H e R}$ under the given conditions. The graph also contains the values of the corresponding transferred heat flow rates $Q$ and the temperature values of helium $T_{\mathrm{HeRO}}$ at the outlet of the gas-cooled fast reactor model.

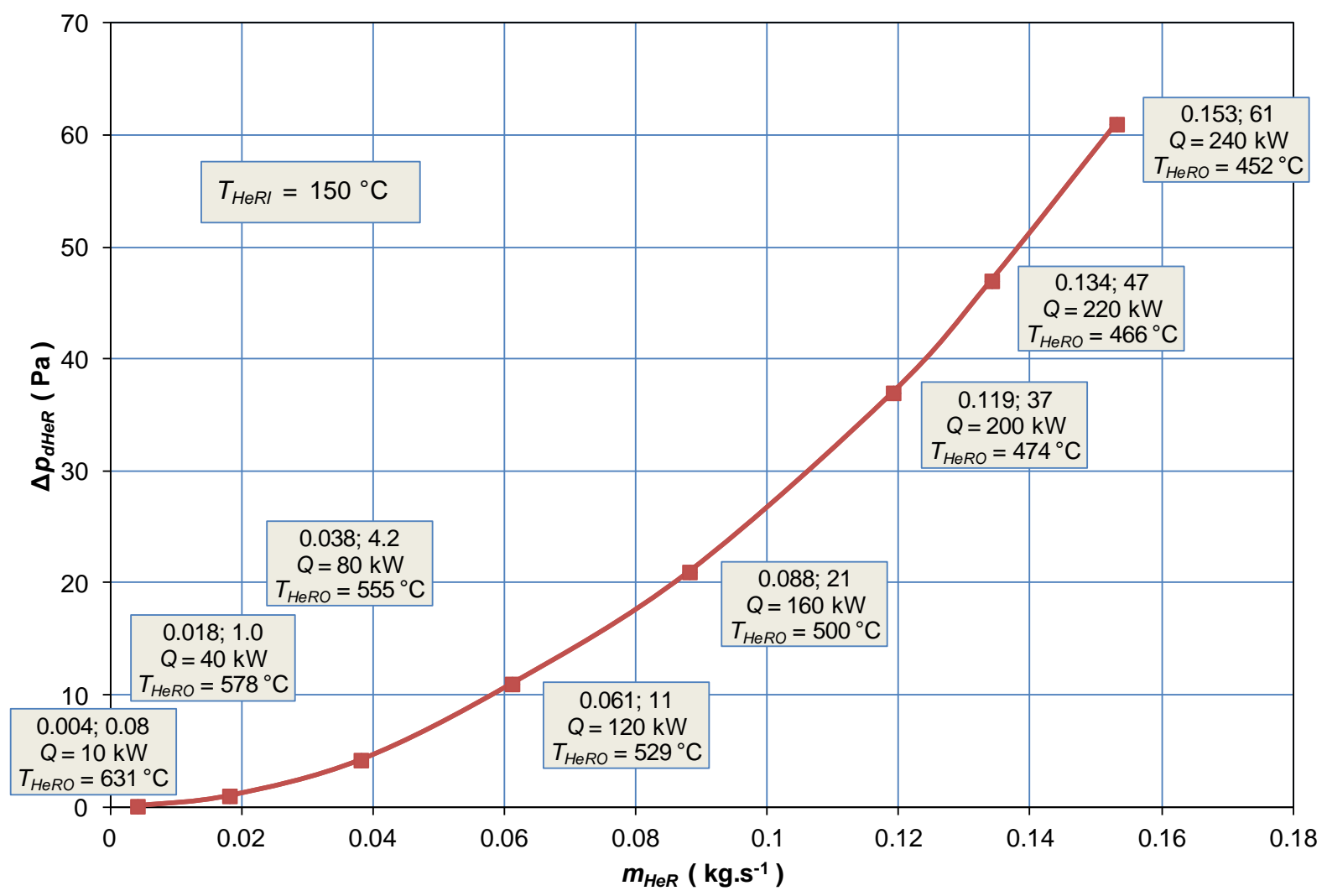

Fig. 4 The dependence of pressure drop on the helium mass flow within the reactor model.

In Fig. 5, the dependence of the pressure drop $\Delta p_{d H e H}$ in the hot piping branch of the helium cooling loop system on the helium mass flow $m_{\mathrm{HeH}}$ is plotted. Fig. 6 shows the dependence of the pressure drop $\Delta p_{d H e C}$ in the cold piping branch of the helium cooling loop system on the helium mass flow $m_{\mathrm{HeC}}$ under the given conditions. 


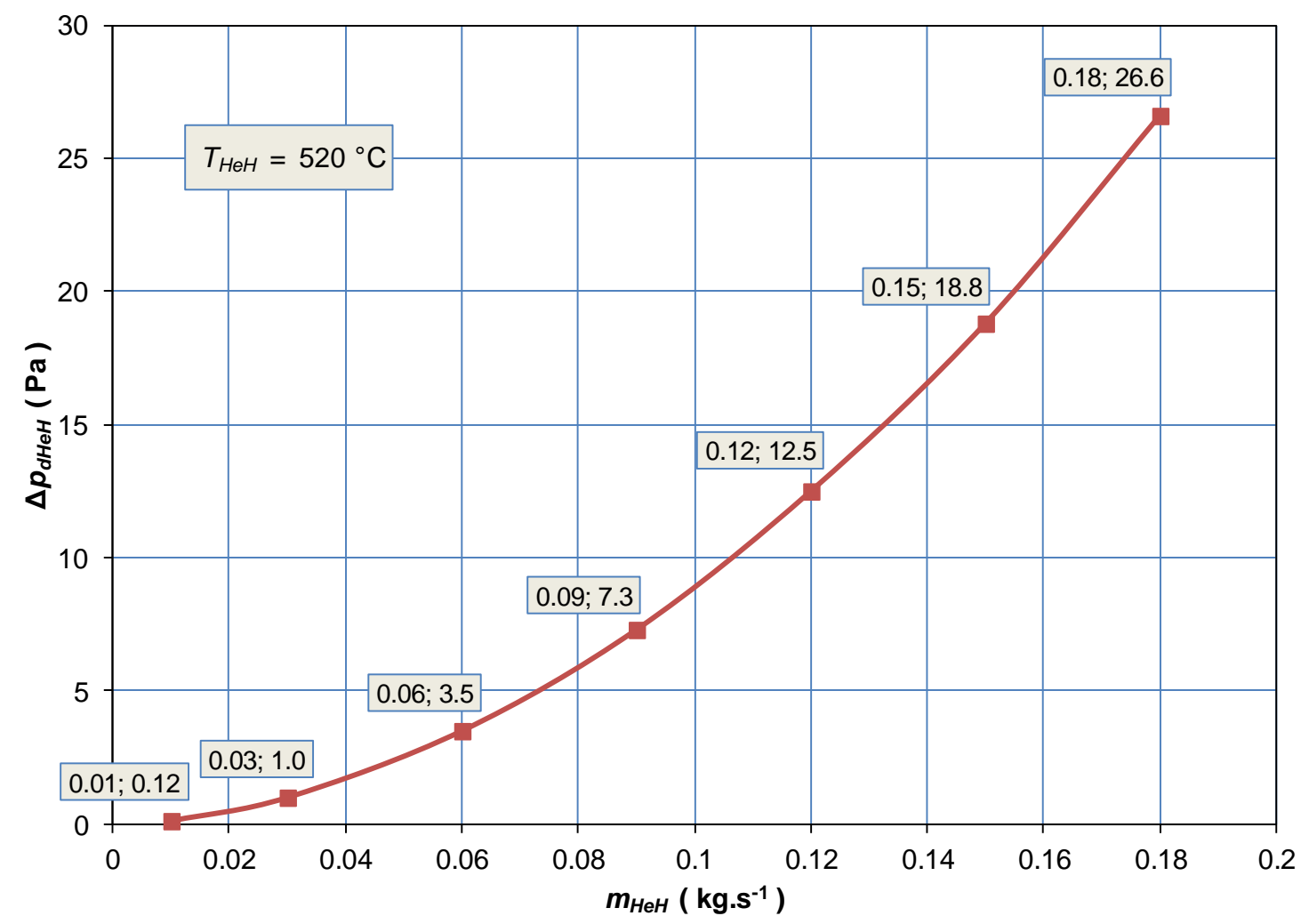

Fig. 5 The dependence of pressure drop on the helium mass flow within the hot piping branch.

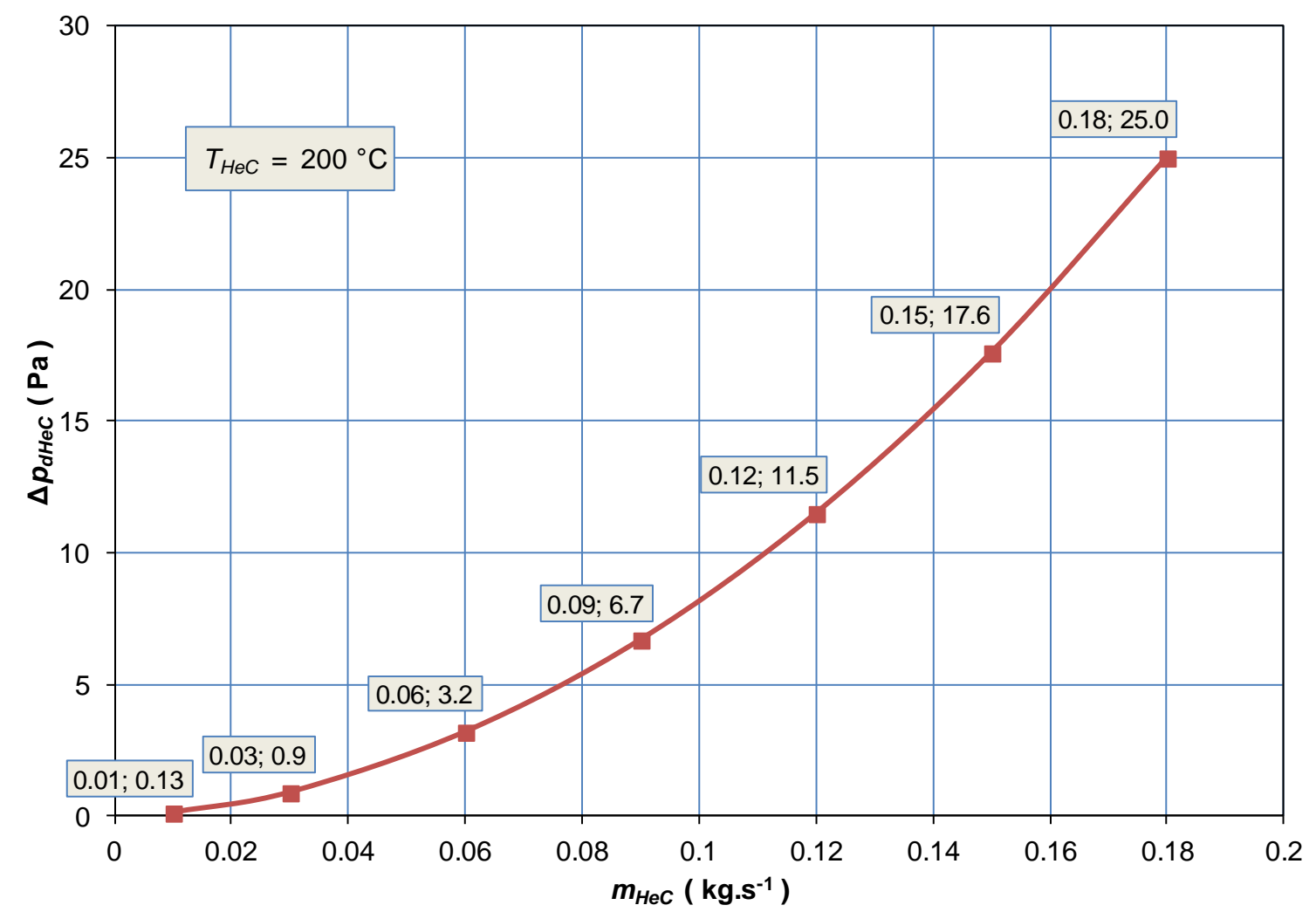

Fig. 6 The dependence of pressure drop on the helium mass flow within the cold piping branch. 


\section{Conclusion}

The results of the calculations document the distribution of the total pressure drop in the high temperature helium cooling loop system with natural circulation of helium for individual components of the system (model of gas-cooled fast reactor, model of the heat exchanger for decay heat removal, hot piping branch and cold piping branch) under defined operating conditions. From the results, it is possible to identify the demand of mechanical energy within the main process components of the cooling system. These results can be useful as input for further hydrodynamic, and thus the thermal optimisation, of such helium cooling loop system.

\section{REFERENCES}

[1] M. Miletić, R. Fukač, I. Pioro, A. Dragunov. Development of gas cooled reactors and experimental setup of high temperature helium loop for in-pile operation. Nuclear Engineering and Design, 2014 (276), 87 - 97

[2] J. Berka, T. Hlinčík, I. Víden, T. Hudský, J. Vít. The design and utilization of a hightemperature helium loop and other facilities for the study of advanced gas-cooled reactors in the Czech Republic. Progress in Nuclear Energy, 2015 (85), 156 - 163

[3] B. Knížat, P. Hlbočan, M. Mlkvik. CFD simulation of a natural circulation helium loop. In Scientific Proceedings Faculty of Mechanical Engineering STU in Bratislava, Nakladatel'stvo STU, Bratislava, 2015, 57 - 62

[4] F. Urban, et al. Modelovanie prirodzenej cirkulácie hélia v experimentálnej héliovej slučke. Výskumná správa projektu Výskumné centrum ALLEGRO, Strojnícka fakulta STU v Bratislave, Bratislava, 2016

[5] V. Kutiš, J. Jakubec, J. Paulech, G. Gálik, T. Sedlár. CFD Analysis of Downcomer of Nuclear Reactor VVER 440. Journal of Mechanical Engineering - Strojnícky časopis, 2016 (66), No. 2, 55 - 62

[6] VDI-Wärmeatlas. 10th edition. VDI-Gesellschaft Verfahrenstechnik und Chemieingenieurwesen (Ed.), Springer-Verlag, Berlin - Heidelberg - New York, 2006

[7] V. Novák, F. Rieger, K. Vavro. Hydraulické pochody v chemickém a potravinářském průmyslu. SNTL, Praha, 1989 